\title{
AN INTEGRATED EXPLORATION TECHNIQUE FOR GROUNDWATER ON A PART OF THE BASEMENT COMPLEX OF SOUTHWESTERN NIGERIA
}

\author{
E. Y. YENNE, A. Y. B. ANIFOWOSE AND M. O. YOHANNA \\ (Received 6 March 2017; Revision Accepted 12 July 2017)
}

\begin{abstract}
Akure is underlain by the basement complex rocks of southwestern Nigeria. It is faced with difficulty in the search for groundwater due to lateral discontinuity of basement lithologies. This study therefore delineates possible groundwater potential zones through the integration of remote sensing and electrical resistivity data. Landsat TM data was digitally processed and used to produce lineament, lineament density and intersection maps while hydrogeological parameters were obtained from electrical resistivity method and used in the production of overburden/fractured map. Weighted overlay method was utilized in ArcGIS ${ }^{\circledR}$ in order to integrate the two maps so as to produce groundwater potential map of the study area. The groundwater potential map showed four major areas of groundwater potentials viz; very low, low, high and very high groundwater potential areas. An average of 0.9445 litres of groundwater is discharge per second in the area i.e., approximately 3, 400litres per hour of groundwater is disharge in th area. However, a critical analysis of borehole yields show that boreholes with the poorest yields pump at a rate of between 0.2 to $0.5 \mathrm{l} / \mathrm{s}$ which is higly inadequate while very good boreholes pump at the rate of 1.14 to $2.16 \mathrm{l} / \mathrm{s}$. Infact, most areas with good yields are cited in the southwestern portions of the study area.
\end{abstract}

KEYWORDS: Electrical resistivity, Groundwater, Remote sensing, Landsat TM, Lineament, Yields.

\section{INTRODUCTION}

The integration of remote sensing and electrical resistivity methods are two important methods for groundwater exploration and mapping for a sustainable water supply in any basement environment. Though, several works have been published on the use of remote sensing and geophysical methods in groundwater potential mapping with Geographic Information System (GIS) platform providing a suitable unifying environment in many Basement rock environments (Greenbaum et al., 1993; Saxena et al., 2004; Sahu and Sahoo, 2006; Goki et al., 2010; Akinluyi 2012), however, this research focuses on such combined methods so as to substantiate and evaluate the extent of the groundwater. Here, various studies either related to or targeted at finding groundwater have been conducted successfully using geophysical methods (Worthington, 1977; Olorunfemi et al., 1999; Olorunfemi et al., 1993, Akintorinwa and Olowolafe, 2012, Mogaji et al., 2011) and/or remote sensing method (Odeyemi et al., 1999, Mogaji et al., 2011, Anifowose and Kolawole, 2012, Yenne, 2015, Dibal et al, 2016) but the increasing needs for sustainable groundwater supply which is the cheapest source of potable water is still emphasized. Thus, the separate use of the two methods in groundwater exploration has encountered different degrees of set-backs and a more reliable solution will be the combination (Srivastava et al., 2012). Yadav and Singh (2007) posited that the integration of various data such as terrain features derived from remote sensing images, hydrogeomorphic details and depth to groundwater table help in generating groundwater potential zone maps which, when complemented with geophysical data, facilitate effective evaluation of groundwater potential zones. Hence, the exploration for groundwater requires a vivid understanding of both surface and subsurface characteristics of the area (Mogaji et al., 2011). This research is aimed at using remote sensing and geophysical methods to explore for surface and subsurface characteristics of water. This was achieved by producing and integrating both lineament and overburden/fractured maps so as to produce a groundwater potential map, and subsequently validated the result with boreholes yield data.

The study area, Akure, has witnessed an upsurge in infrastructural development and increase in human population, since becoming the capital of Ondo State, Nigeria in 1976. The demand for potable water for human consumption, industrial and agricultural needs has grown astronomically over the years (Olorunfemi et al., 1999). Hence, supply has been grossly inadequate to the extent that inhabitants depend on surface water. Hence, it is in view of the quest for potable and sufficient amount of water in Akure that the study has been carried out where it employed the most recent and tenable methods of exploration to delineate groundwater potential of the area. Therefore, the study will produce lineament maps from remote sensing and an overburden/fractured map from electrical resistivity data

E. Y. Yenne, Department of Geology, University of Jos, P.M.B 3084, Jos, Nigeria.

A. Y. B. Anifowose, Department of Remote Sensing \& GIS, Federal University of Technology, Akure, Nigeria.

M. O. Yohanna, Department of Geology, University of Jos, P.M.B 3084, Jos, Nigeria.

(C) 2018 Bachudo Science Co. Ltd. This work is licensed under Creative Commons Attribution 4.0 International license. 
with the sole purpose of generating a groundwater potential map which will henceforth be evaluated by borehole yield data.

\section{THE STUDY AREA}

The study area covers Akure metropolis and its environs situated in the Southwestern part of Nigeria. Geographically, it is located between Latitudes $7^{0} 12$ and $7^{\circ} 19^{\prime}$ North, and Longitudes $5^{\circ} 08$ and $5^{\circ} 18^{\prime}$ East (Fig. 1). The areal extent of the study portion is approximately 234 square kilometers. It is underlain by crystalline Precambrian Basement Complex rocks comprising migmatite-gneisses, granite-gneisses, charnockites, quartzites and granites (Fig. 2) (Olarewaju, 1981). The charnockites weather into low permeability clayey (low resistivity) materials with low groundwater discharge capacity, while the gneisses and granites weather into higher permeability sandy clay and clayey sand and sand with higher groundwater discharge capacity (Yenne, 2015). The quartzites fracture excellently to increase permeability. Groundwater in the study area is primarily recharged by precipitation (rainfall) and secondarily by lateral flow from rivers and their tributaries (Olorunfemi et al., 1999). It is discharged through springs, seepages, flow into rivers and streams and abstraction through shallow and deep wells. The area shows varieties of structural setting such as foliations, folds, faults, joints and fractures which give very good groundwater storage. Thus, the relatively E-W lineament orientation set in the area has been observed to exert significant controls on the preferred orientations of groundwater occurrence (Anifowose and Kolawole, 2012). Generally, five aquifer types have been identified in the study area; weathered layer aquifer, weathered/fractured (unconfined) or partly weathered aquifer, weathered/fractured (confined) aquifers, weathered/fractured unconfined/fractured (confined) aquifer and fractured (confined) aquifer (Olorunfemi and Fasuyi, 1993).
The climatic condition of the area is typical of the pattern shown in Southwestern part of Nigeria. The weather is influence mainly by two prominent seasons; the wet and the dry seasons. The wet season usually commenced from April and ends at October and the dry season spans between November and March. During June and September, rainfall is usually very high leading to high probability of flooding, and soil erosion but then ensures maximum recharge of groundwater. It is during these months that the peak of rainfall occurs, hence, sporadic and heavy down pours are recorded with its consequent destruction of life and properties. The area experiences high annual mean rainfall of $1333.2 \mathrm{~m}$ (Owoyemi, 1996). The annual mean temperature ranges from approximately $22^{\circ} \mathrm{C}$ at minimum temperature to $31^{\circ} \mathrm{C}$ at maximum temperature. Evaporation is usually low most especially from June to September thereby encouraging surface water penetration to the water table. The topography is generally rugged with hills showing up in most parts of the area though the center is low-lying. In some areas, inselbergs are prominent causing a scenic undulating topography. The northern and southern portions of the study area record the highest elevation and hence relatively steep sloping. In general, the land rises from the lowlands of height 290 meters in the south Eastern and Western to the rugged hills of the north and south around Igoba and Oke-Aro respectively. The more prominent hill is around Oke-Aro in the south rising up to 480 meters (above mean sea level). Since the study area is underlain by crystalline rocks, the occurrence of groundwater depends on the thickness of the weathered rocks and the presence or absence of fractures within the crystalline rocks. The Rivers Owena and Ala and their tributaries constitute the surface water resources of the study area. Groundwater in the study area is contained in weathered and or fractured/jointed basement columns, while hydraulic connection makes the water table to be dynamic and constantly flow from area of high pressure to low pressure. 
AN INTEGRATED EXPLORATION TECHNIQUE FOR GROUNDWATER ON A PART OF THE BASEMENT COMPLEX

47

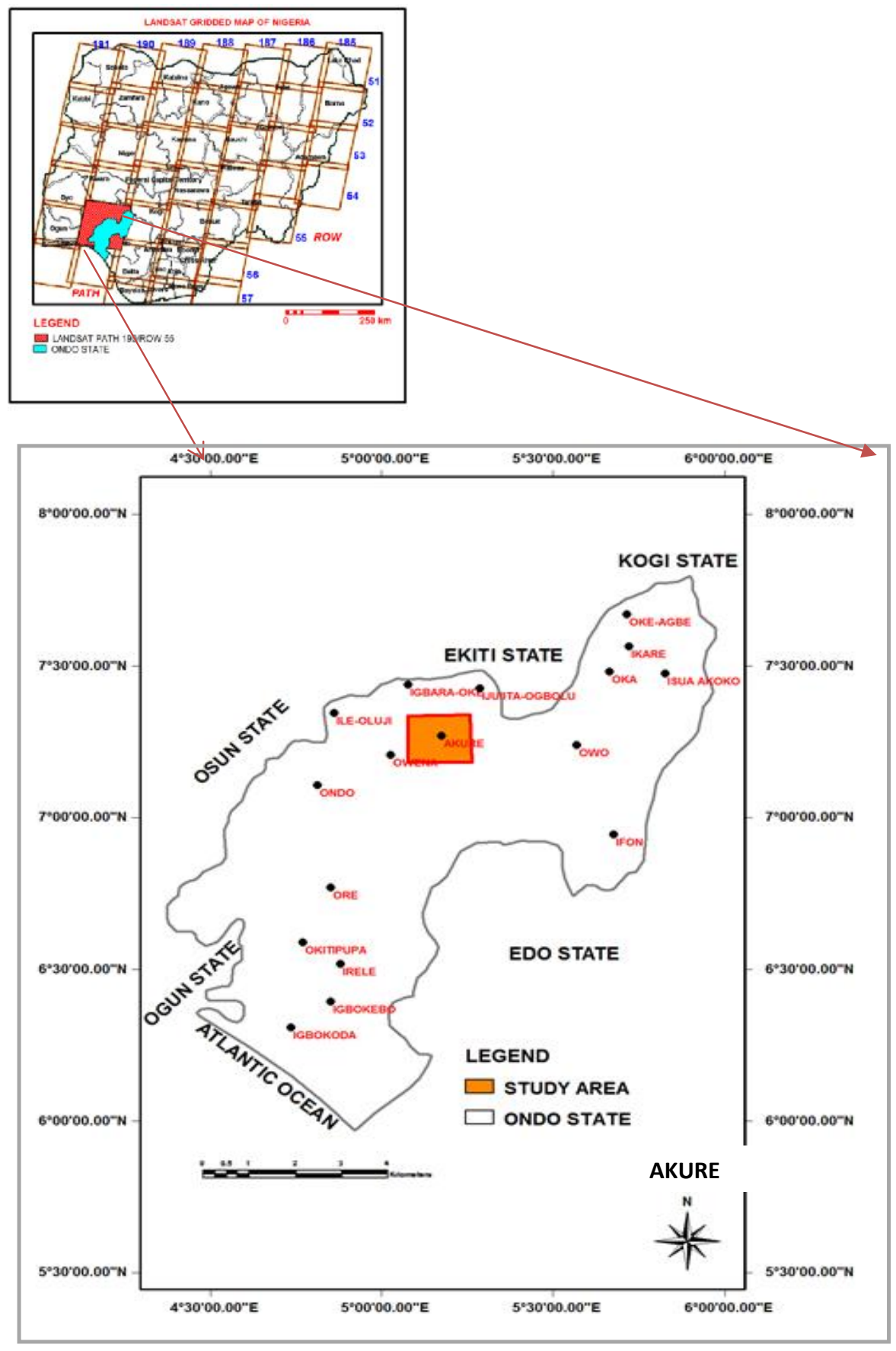

Fig. 1: Location map of the study area. 


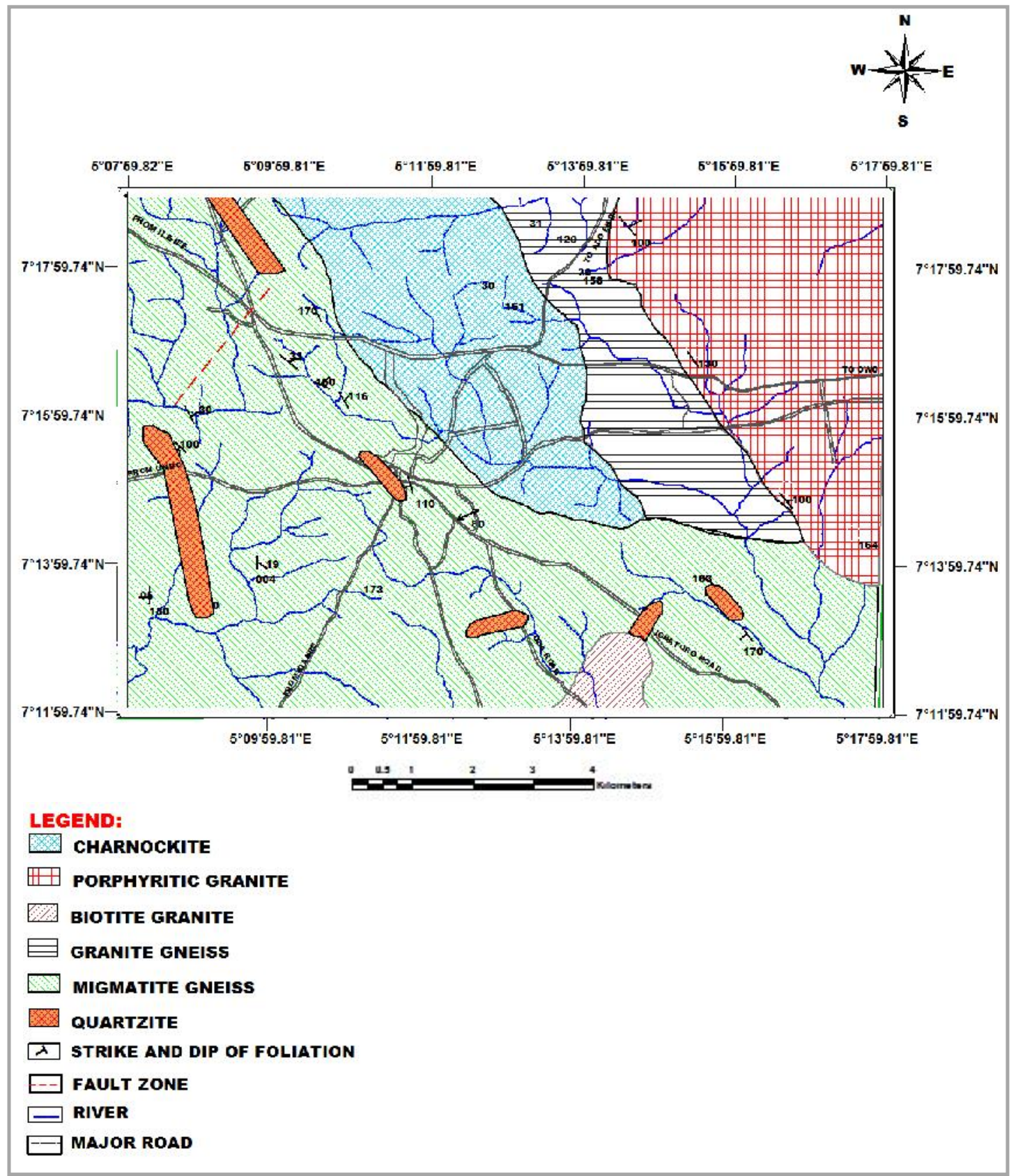

Fig. 2: Geological map of the study area (after Olarewaju, 1981).

\section{MATERIALS AND METHODOLOGY}

The review of relevant literature was carried out with subsequent reconnaissance survey of the area of study. Primary and secondary datasets such as borehole, VES data, geological map, topographic maps, Landsat Thematic Mapper (TM) etc., were acquired. Landsat TM band 5 covering the study area was subsetted from the full scene of path 190 and row 055, and then digitally processed using methods of spatial and spectral enhancement techniques. The Normalized Difference Vegetation Index (NDVI) was calculated from $\mathrm{ENVI}^{\circledR} \quad 4.3$ software and then applied directional convolutions filter of $3^{\star} 3$ kernel filter size of between $0^{0}$ and $180^{\circ}$ angles for lineament extraction. Seventy one (71) lineaments were obtained in $\operatorname{ArcGIS}^{\circledR}$ software using the lineament construction procedures as postulated by Kim et al., (2004). Lineament density and intersection maps were also generated. The generated lineament map was reclassified in $\operatorname{ArcGIS}^{\mathrm{TM}}$ into nine classes each; from 1 to 9 where class value 1 represented the least suitable area for groundwater and 9 represent the most suitable area. Electrical resistivity method using Schlumberger configurations and Vertical Electrical Soundings (VES) field techniques was employed to generate data for the study area. The setup was such that the spread is perpendicular to the direction of the major lineament trend obtained from remote sensing method. A resistivity meter was used to send current into the ground and the degree of resistance to the flow of the current by the lithologies was measured. The apparent resistivitv. oa. obtained 
was manually plotted on log-log paper, curved matched with master curves and the parameters deduced in terms of resistivity and thickness values were transferred into IP12Win ${ }^{\circledR}$ for computer modeling of the geoelectrical subsurface parameters. The parameters where analyzed and an overburden/fracture thickness map was produced showing the subsurface characteristics and aquifer types of the study area. Finally, the overburden thickness map was reclassified and assigned weight value as that of the lineament map.

The reclassified maps from the remote sensing and electrical resistivity methods were then overlaid using weighted overlay module. The weighted overlay module in ArcGIS ${ }^{\text {TM }}$ was used to integrate the two (2) reclassified maps using a common measurement scale and weights according to its importance to groundwater potentiality (availability). The weight or the percentage of influence of a feature in a reclassified map to groundwater occurrence was assigned based on perceived and judgmental degree of importance of each feature to the study. The final map was produced by Weighted Linear Combination (WLC) where each class is accorded individual's weight (\% influence) and multiplied by the map cell values and then the result added together to form the groundwater model map of the area.

Mathematically, the suitability groundwater potential map, $\mathrm{S}$ is written as

$\mathrm{S}=\Sigma\left\{\left(\mathrm{W}_{\mathrm{i}}\right) \times\left(\mathrm{X}_{\mathrm{i}}\right)\right\}$

Where $S=$ Suitability (Integer), $W_{i}=$ Weight for each factor map, $X_{i}=$ cell values of Individual map, $i=$ number of reclassified maps
Thirty-one (31) borehole yield data were superimposed on the groundwater potential and lineament maps of the study area in ArcGIS ${ }^{\text {TM }}$. The yields were employed to evaluate the accuracy of the groundwater potential map also.

\section{RESULTS AND DISCUSSION}

\section{Remote Sensing}

Landsat TM band 5 was utilized for the extraction of seventy one (71) lineaments within the study area (Fig. $3)$. The lineament traces from Normalized Difference Vegetation Index (NDVI) showed the concentration of lineaments with high groundwater potential around the southwestern part of the area (Fig. 4). It is important to emphasize here that all duplications registered during digitization were corrected in ArcView by remove-node and generalize files. Finally, lineament density and intersection maps were generated (Figs. 5 and 6) and it showed that the southwestern part of the study area contains lineaments that are of high groundwater potential hence it was reclassified (Fig. 7). The lineaments in the study area trend mainly in N-S, NE and NW directions and as such serves as storage points and conduits for groundwater movement. In the central part where relief is high and regolith thickness is low, productivity is good due to the presence of intersecting lineaments. The lineaments host groundwater especially in the southwestern part as evidenced by the NDVI map which shows the presence of vegetation aligned with such structures. The study area is a basement complex terrain which implies that the rock types have undergone series of tectonic deformation which created secondary porosity and permeability in the form of fractures within lithologies. Such weakness zones are good pathways for water

flow. 


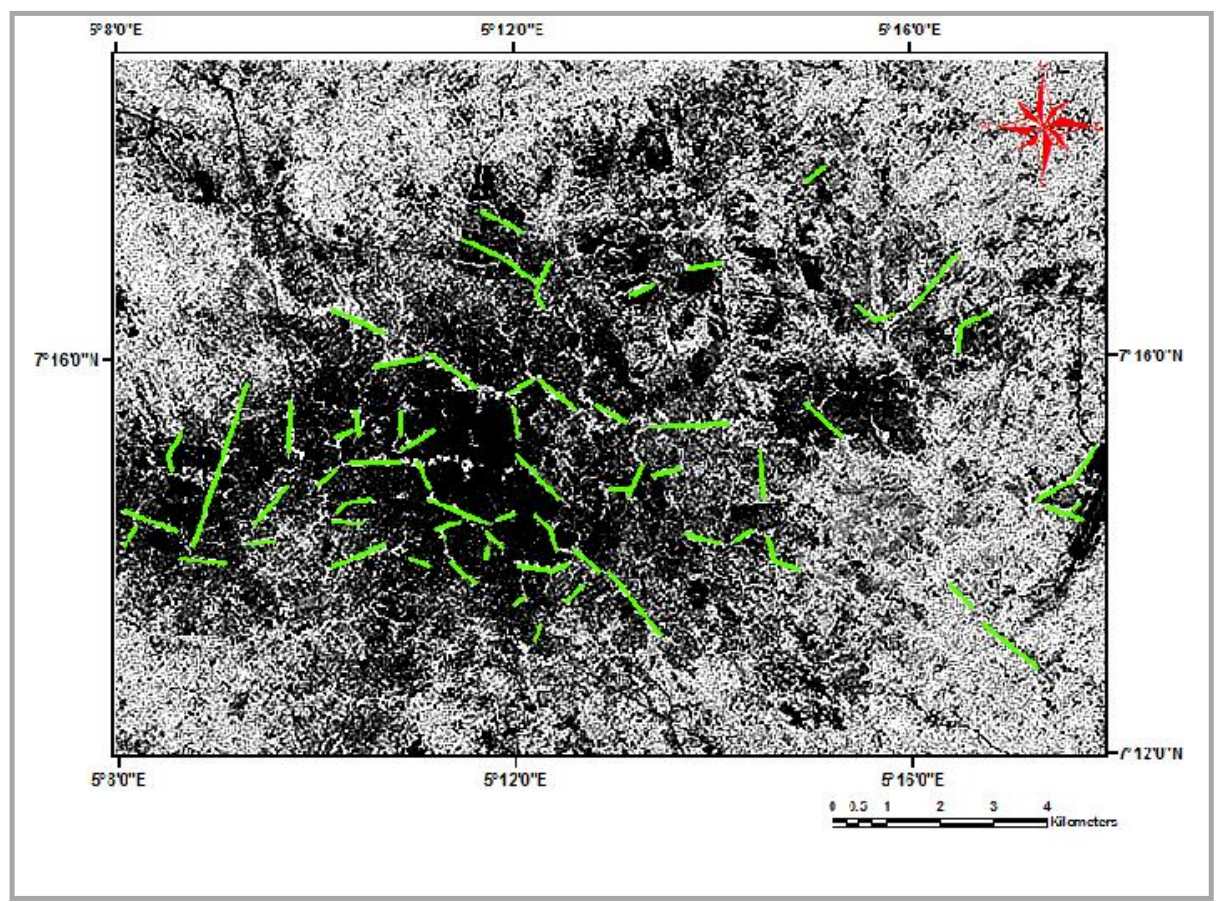

Fig. 3: Lineament traces of the study area on NDVI.

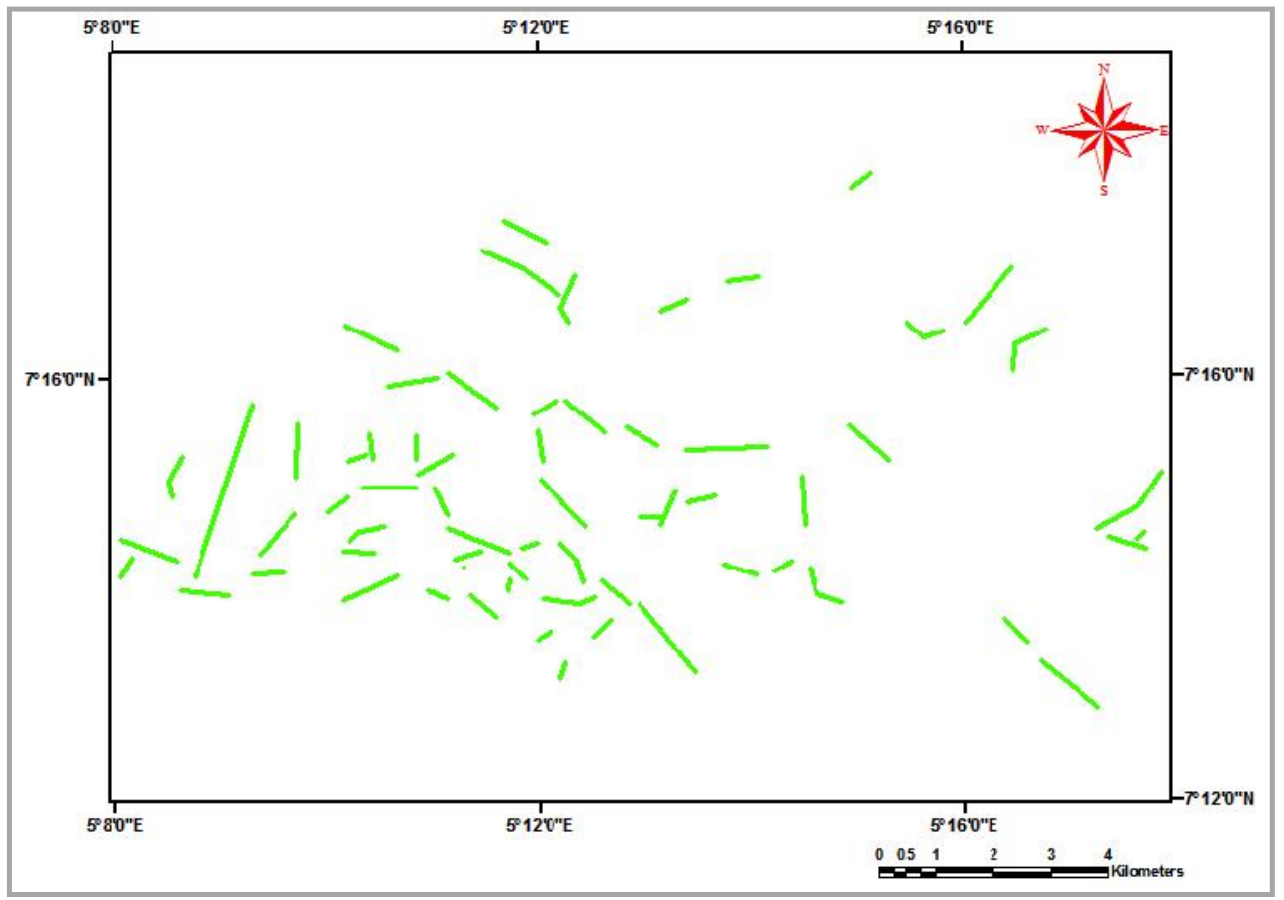

Fig. 4: Lineament map of the area. 


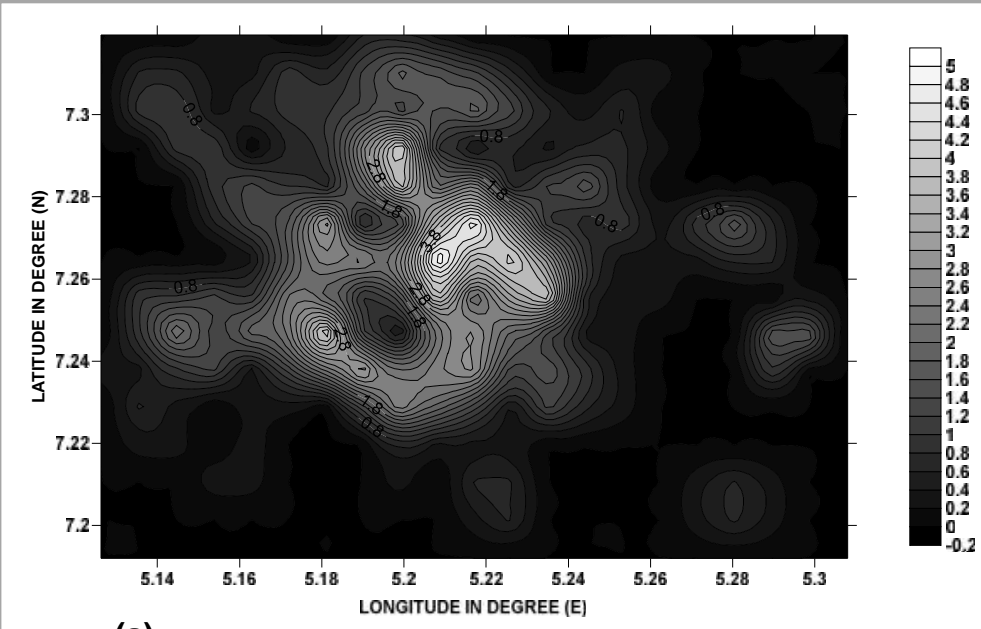

(a)

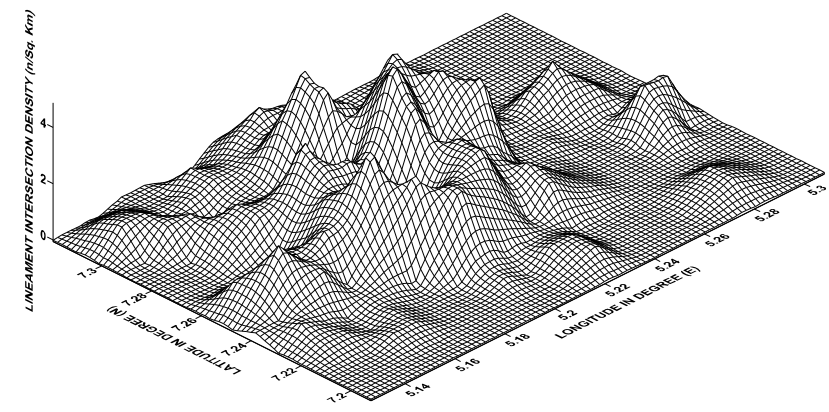

(b)

Fig. 5: Lineament intersection density map (a) Filled contour map (c) 3D wireframe map

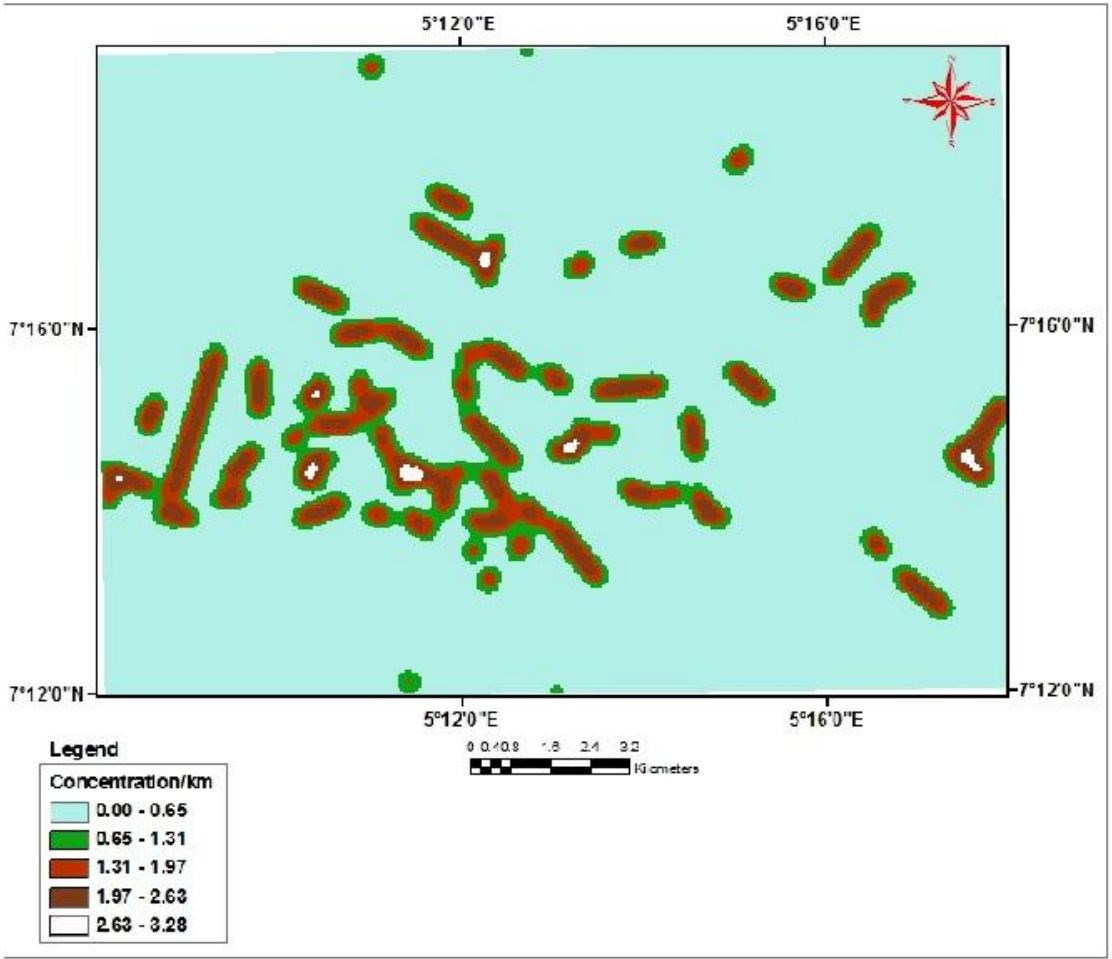

Fig. 6: Lineament density map of the study area 


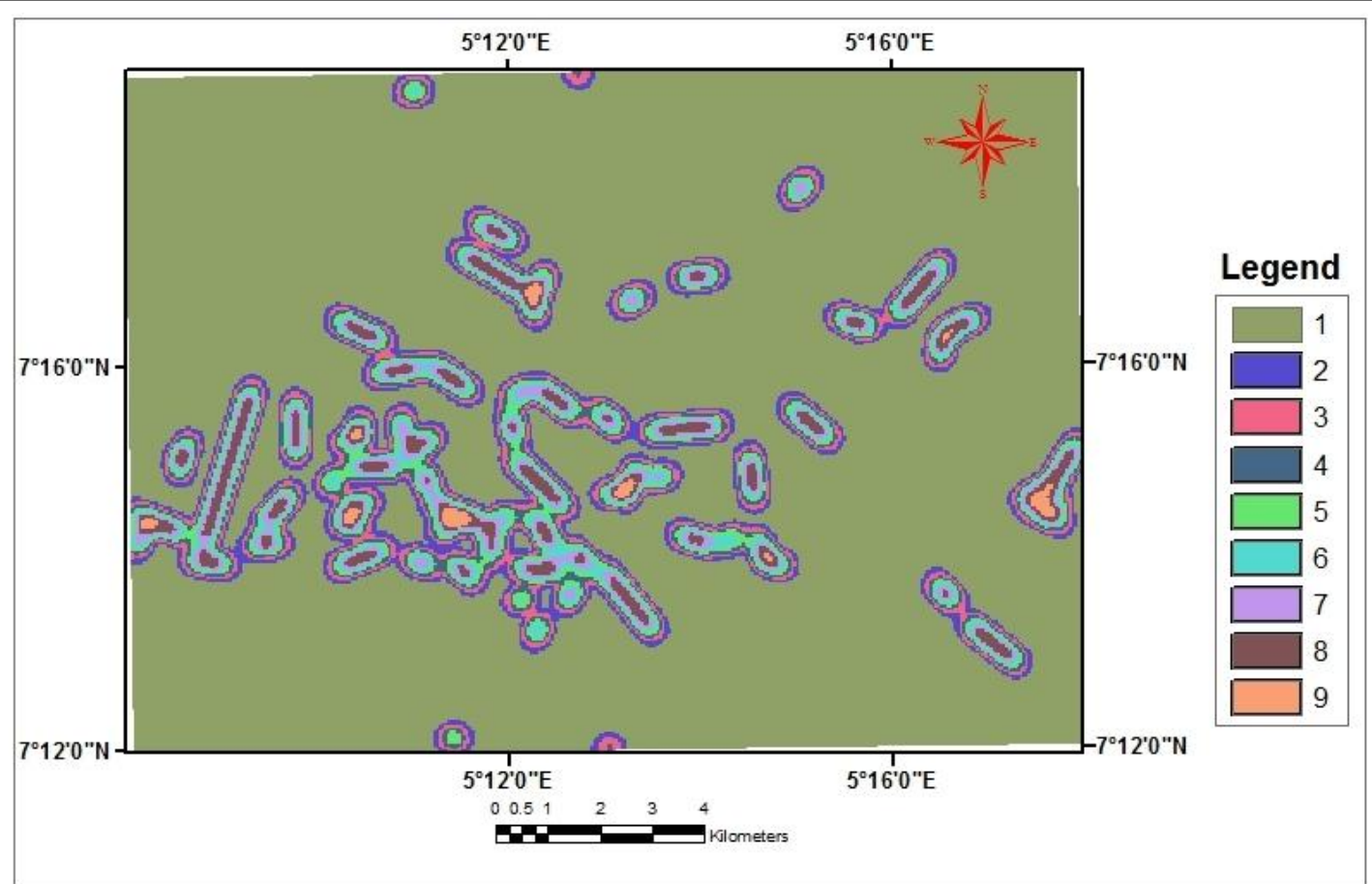

Fig. 7: Reclassified lineament map of the study area.

\section{Electrical Resistivity}

One Hundred and ten (110) Vertical Electrical Sounding (VES) points were investigated in the study area; however, fourteen (14) representative samples are presented (Table 1) where the points over the area are summarized into their respective number of layers, curve type, resistivity and thicknesses of layers, and depth to bedrock or overburden thicknesses. The VES points were used to obtain seven (7) profiles (Fig. 8) with their respective geoelectric layers.

The geo-electric section along profile A1-A2 (Fig. 9) connects VES points $84,82,81,73,74,13,76$, and 72. The subsurface layers identified in this section are the topsoil, weathered lateritic layer, sandy soil, highly weathered and fractured basement rock, and fresh basement rock. The topsoil has thickness ranging from $0.3 \mathrm{~m}$ to $1.8 \mathrm{~m}$. The weathered lateritic layer has thickness ranging from $0.4 \mathrm{~m}$ to $6.6 \mathrm{~m}$. The sandy soil thickness ranges from $3 \mathrm{~m}$ to $24.2 \mathrm{~m}$. The highly weathered layer is observed beneath VES 72,73 and 82 with thickness ranging from $9.8 \mathrm{~m}$ to $19.4 \mathrm{~m}$. VES 13 and 72 show fracturing of the basement rock at a depth of between $15.3 \mathrm{~m}$ and $48.4 \mathrm{~m}$. Geo-electric section along profile B1-B2 connects VES 50,63, 59, 62, 66, 67 and 68 (Fig. 10). Six geo-electric layers observed from this profile are the top soil, the weathered lateritic layer, sandy soil, coarse sand, highly weathered basement rock and fresh basement rock. The thickness of the top soil varies from $0.2 \mathrm{~m}$ to $4.5 \mathrm{~m}$. The weathered lateritic layer thickness ranges from $0.6 \mathrm{~m}$ to $9.8 \mathrm{~m}$. The sandy soil which is observed in VES 50,63, 62, 67 and 68 overlies the coarse sand and has a thickness ranging from $0.8 \mathrm{~m}$ to $12.1 \mathrm{~m}$. The coarse sand is noted in VES 63,62 and 68 has a thickness range from $3.6 \mathrm{~m}$ to $6.9 \mathrm{~m}$. Finally, the highly weathered layer is observed in VES 63 and 62 with thickness of 8.2 and 6.4 respectively. The ran-olertrir certion alnno nrofile C.1_.? (Fir 11) connects VES points $97,99,90,42,93,88$. The subsurface layers identified are the topsoil, weathered lateritic layer, sandy soil, highly weathered and fractured basement rock, and fresh basement rock. The topsoil has thickness ranging from $0.3 \mathrm{~m}$ to $2.2 \mathrm{~m}$. The weathered lateritic layer has thickness ranging from $1.1 \mathrm{~m}$ to $12.8 \mathrm{~m}$. The sandy layer is observed in VES 42 and 93 with thicknesses of $3.2 \mathrm{~m}$ and $9.8 \mathrm{~m}$ respectively. The highly weathered layer overlies the basement rock and is observed only in VES 93 with thickness of $10.2 \mathrm{~m}$. VES 99, 96, 89, 87 and 91 define the geo-electric section along profile D1-D2 (Fig. 12). Five layers are identified in this geo-electric section. The topsoil with a thickness range between $0.9 \mathrm{~m}$ and $2.2 \mathrm{~m}$ lies on top. The weathered lateritic layer has thickness range from $1 \mathrm{~m}$ to $14.5 \mathrm{~m}$. Underneath this layer is the sandy soil layer which is not present in VES 99. It has thickness that range between $2.3 \mathrm{~m}$ and $34.2 \mathrm{~m}$. The next layer lies on top of the basement rock in VES 89 section with a thickness of $7.1 \mathrm{~m}$. The geo-electric section along profile E1-E2 (Fig. 13) connects VES points23, 18, 11 and 34. The subsurface layers identified are the topsoil, sandy soil, highly weathered and fresh basement rock. The topsoil has thickness ranging from $0.5 \mathrm{~m}$ to $2.4 \mathrm{~m}$. The sandy soil layer ranges in thickness from $1.7 \mathrm{~m}$ to $12.6 \mathrm{~m}$. The highly weathered layer overlies the basement rock and is not observed in only VES 34 but range in thickness from $9.4 \mathrm{~m}$ and $19.4 \mathrm{~m}$. F1-F2 profile connects VES 14, 3 and 4 and the geo-electrical section (Fig. 14). The subsurface layers identified in this section are the topsoil, the weathered lateritic layers, the sandy soil layer, highly weathered and or fractured rocks and the fresh basement rock. The topsoil has thickness ranging from $0.7 \mathrm{~m}$ to $1.3 \mathrm{~m}$. The weathered lateritic layer have thickness ranging from $1 \mathrm{~m}$ to $2 \mathrm{~m}$ while the sandy soil layer thickness ranges from $3.9 \mathrm{~m}$ to $5.7 \mathrm{~m}$ though VES is highly fractured to a thickness of 48.4. The highly 
weathered basement layer is observed beneath VES 23 and 18 with thickness of $34.9 \mathrm{~m}$ to $6.2 \mathrm{~m}$ respectively.

The geoelectric parameters (apparent resistivity, thickness of layers and the depth to bedrock) show the depth from the topsoil of the borehole to the fresh bedrock beneath subsurface as well as fractured zones.
This overburden thickness section also showed the topsoil, the weathered layer and fracture zones where groundwater is most likely to be stored. The depth to the bedrock varies from about $5 \mathrm{~m}$ to about $50 \mathrm{~m}$ but areas with bedrock fractures extend to about $80 \mathrm{~m}$ (Fig. 15). The reclassified map shows nine classes with the largest number having the thickest overburden (Fig. 16).

Table 1: Summary of results from representative VES data

\begin{tabular}{|c|c|c|c|c|c|c|c|c|c|c|c|c|c|c|}
\hline \multirow[t]{2}{*}{$\begin{array}{l}\text { VES } \\
\text { NO }\end{array}$} & \multirow[t]{2}{*}{$\begin{array}{l}\text { NO. of } \\
\text { Layers }\end{array}$} & \multirow[t]{2}{*}{$\begin{array}{l}\text { Curve } \\
\text { type }\end{array}$} & \multicolumn{6}{|c|}{ Resistivity of layers ( -m) } & \multicolumn{5}{|c|}{ Thickness of layers (m) } & \multirow[t]{2}{*}{$\begin{array}{l}\text { Depth to } \\
\text { bedrock } \\
\text { (m) }\end{array}$} \\
\hline & & & $\rho 1$ & $\rho 2$ & $\rho 3$ & $\rho 4$ & $\rho 5$ & $\rho 6$ & H1 & $\mathrm{H} 2$ & H3 & H4 & H5 & \\
\hline 2 & 3 & $\mathrm{~K}$ & 66.2 & 480.2 & 116 & & & & 2.4 & 26.6 & & & & 29.1 \\
\hline 3 & 5 & $\mathrm{HKH}$ & 144.4 & 108.1 & 160.4 & 90.3 & 961.2 & & 0.8 & 1 & 3.9 & 6.2 & & 11.9 \\
\hline 11 & 4 & Q & 1279.9 & 1001.1 & 372.5 & 233.6 & & & 2.4 & 8.7 & 16.4 & & & 27.5 \\
\hline 13 & 4 & $A$ & 71 & 48 & 180 & 724 & & & 0.8 & 3.4 & 48.4 & & & 52.6 \\
\hline 19 & 4 & $\mathrm{HA}$ & 721 & 174.2 & 706.9 & 6215.6 & & & 0.9 & 6.3 & 22.8 & & & 29.9 \\
\hline 20 & 3 & QA & 166.8 & 79.1 & 2230.6 & & & & 0.7 & 14.5 & & & & 15.3 \\
\hline 23 & 4 & $\mathrm{HK}$ & 1060.2 & 147.6 & 25885.8 & 484.5 & & & 0.5 & 6.2 & 14.2 & & & 20.9 \\
\hline 26 & 3 & $\mathrm{H}$ & 94.9 & 11.2 & 619.3 & & & & 0.7 & 8.7 & & & & 9.5 \\
\hline 55 & 5 & $\mathrm{KHA}$ & 234.9 & 356.2 & 138.9 & 374 & 24600 & & 0.6 & 1.5 & 3.2 & 35.6 & & 38.7 \\
\hline 72 & 6 & $\mathrm{KH}$ & 83.5 & 386.8 & 29.9 & 353.9 & 46.6 & 12085 & 1.6 & 1.2 & 3 & 10.5 & 15.3 & 31.6 \\
\hline 81 & 4 & $\mathrm{QH}$ & 288.6 & 198.3 & 26.3 & 907.2 & & & 0.5 & 3.1 & 3.5 & & & 7.1 \\
\hline 83 & 5 & $\mathrm{KHQ}$ & 1744.6 & 3562.9 & 843.1 & 1579 & 116.9 & & 0.8 & 0.9 & 3.8 & 7.5 & & 13 \\
\hline 85 & 5 & AKH & 63.8 & 178.4 & 411.3 & 39.2 & 20074 & & 0.4 & 5 & 5.5 & 10 & & 20.9 \\
\hline 93 & 5 & AK & 37 & 181 & 519 & 20857 & 87.8 & & 0.3 & 2.9 & 9.8 & 10.2 & & 23.2 \\
\hline
\end{tabular}

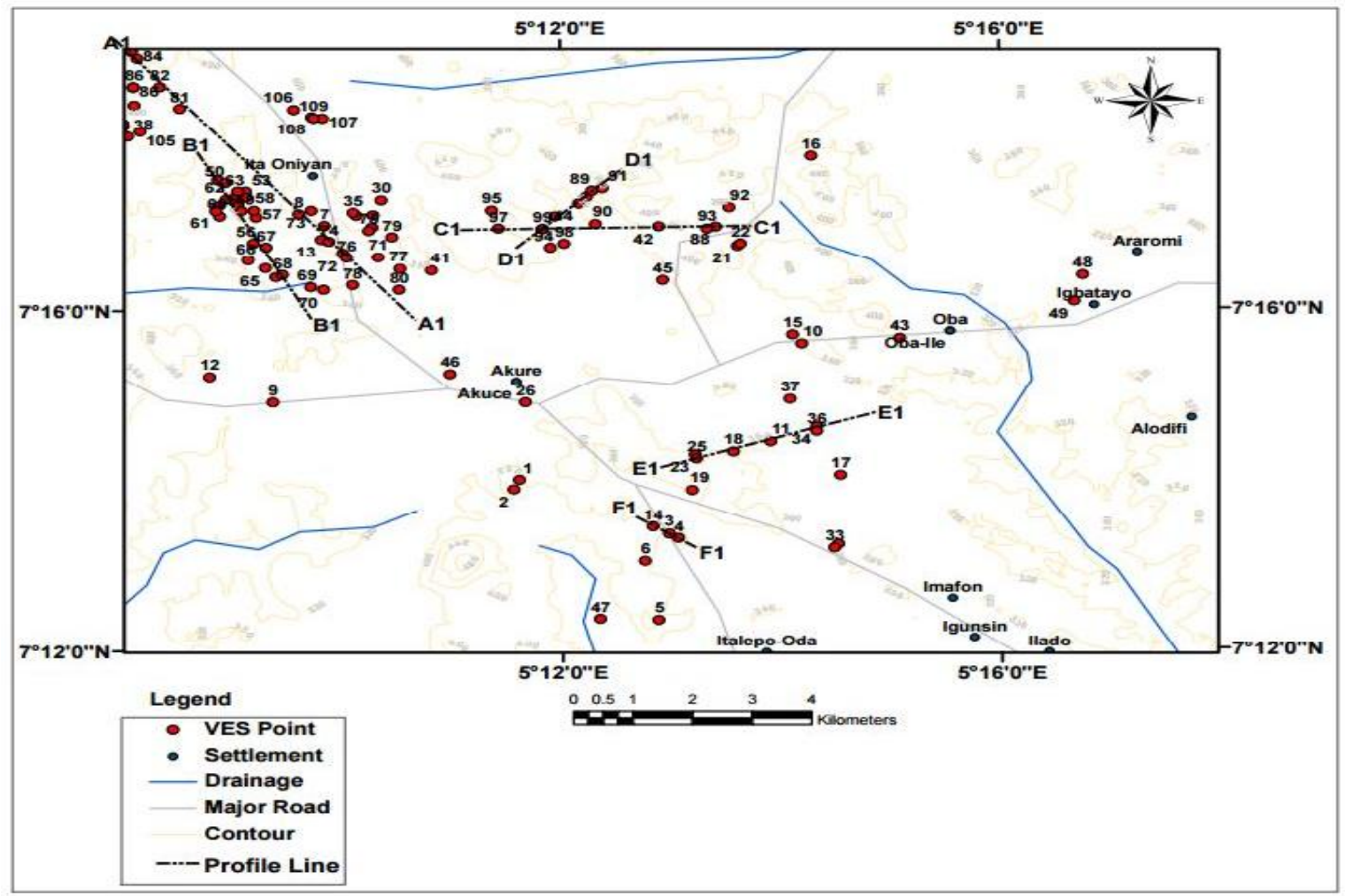

Fig. 8: Location Points of VES and Selected profiles 


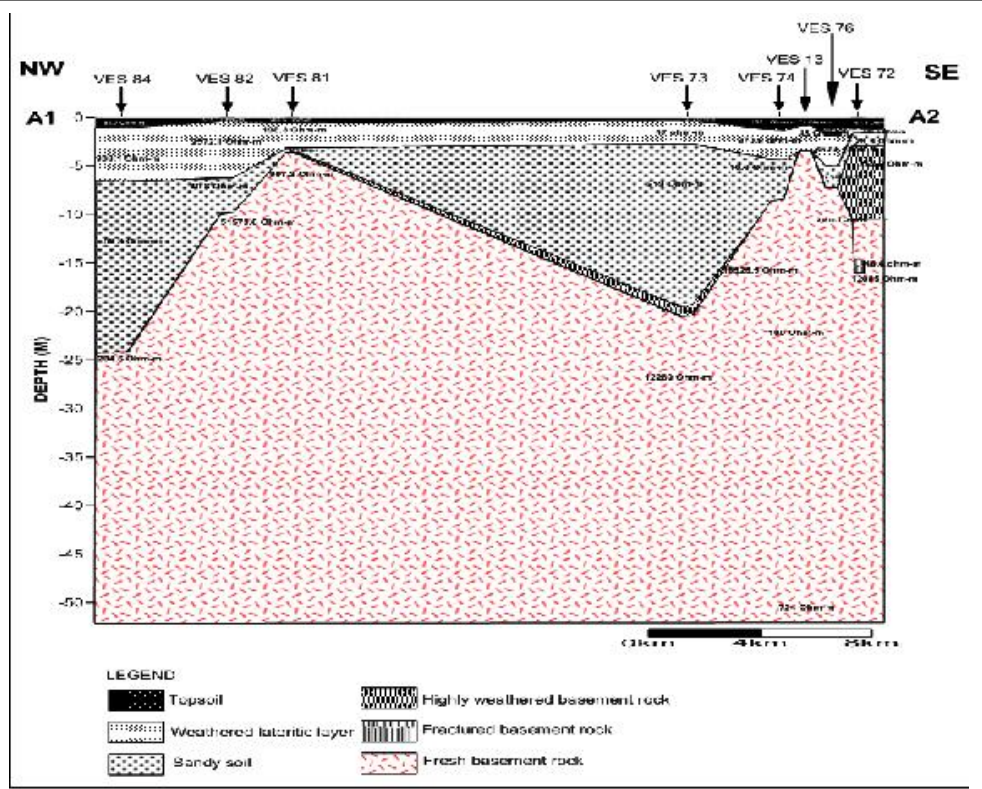

Fig. 9: Geo-electric section along profile A1-A2.

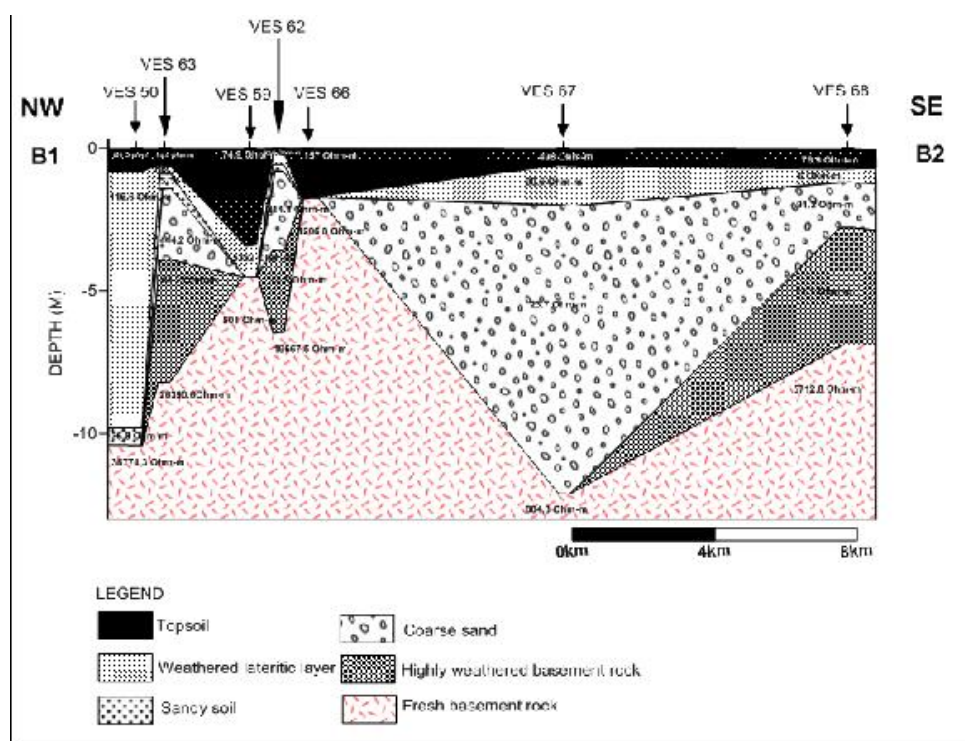

Fig. 10: Geo-electric section along profile B1-B2.

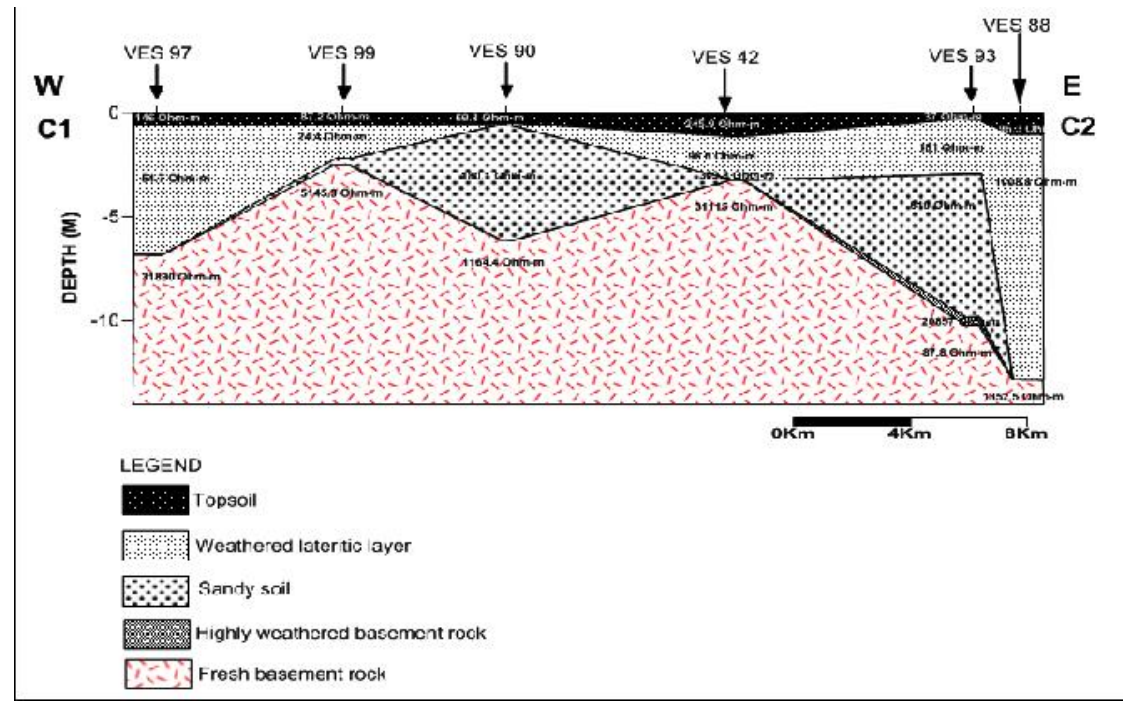

Fig. 11: Geo-electric section along profile C1-C2. 


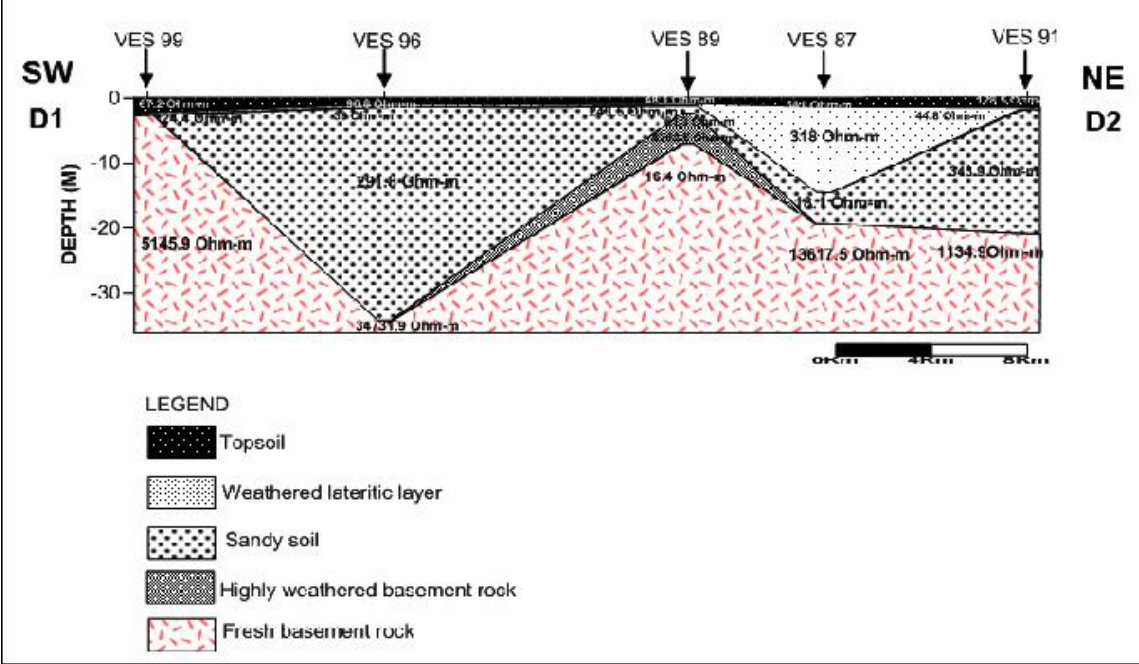

Fig. 12: Geo-electric section along profile D1-D2.

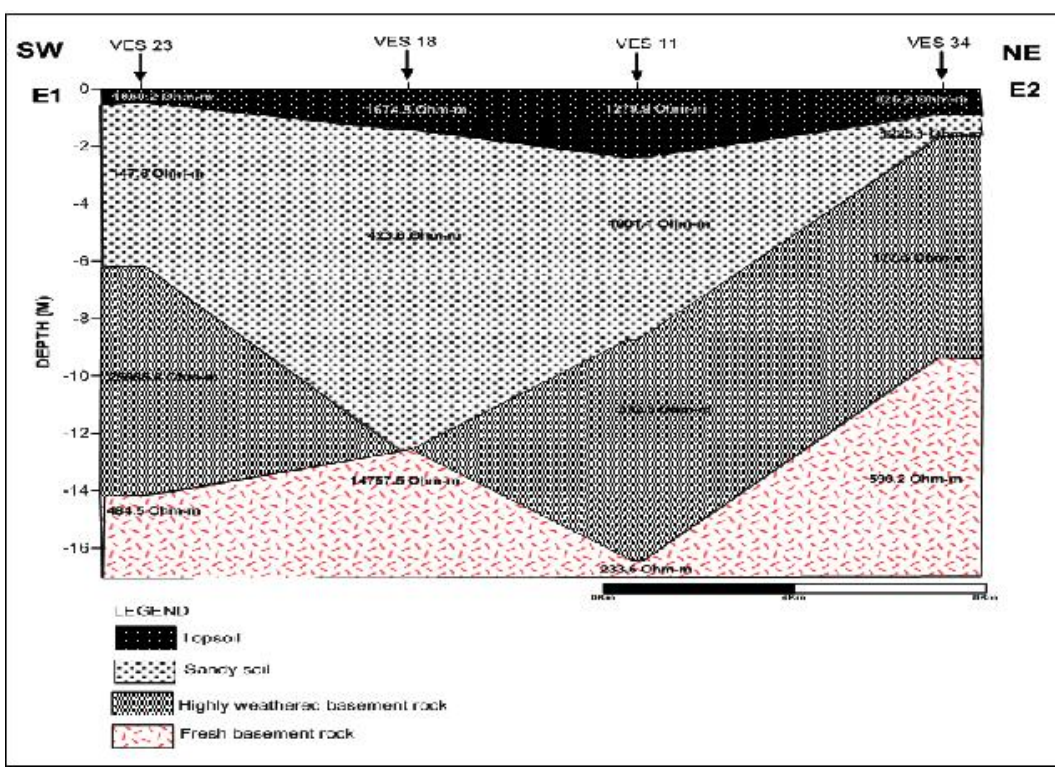

Fig. 13: Geo-electric section along profile E1-E2.

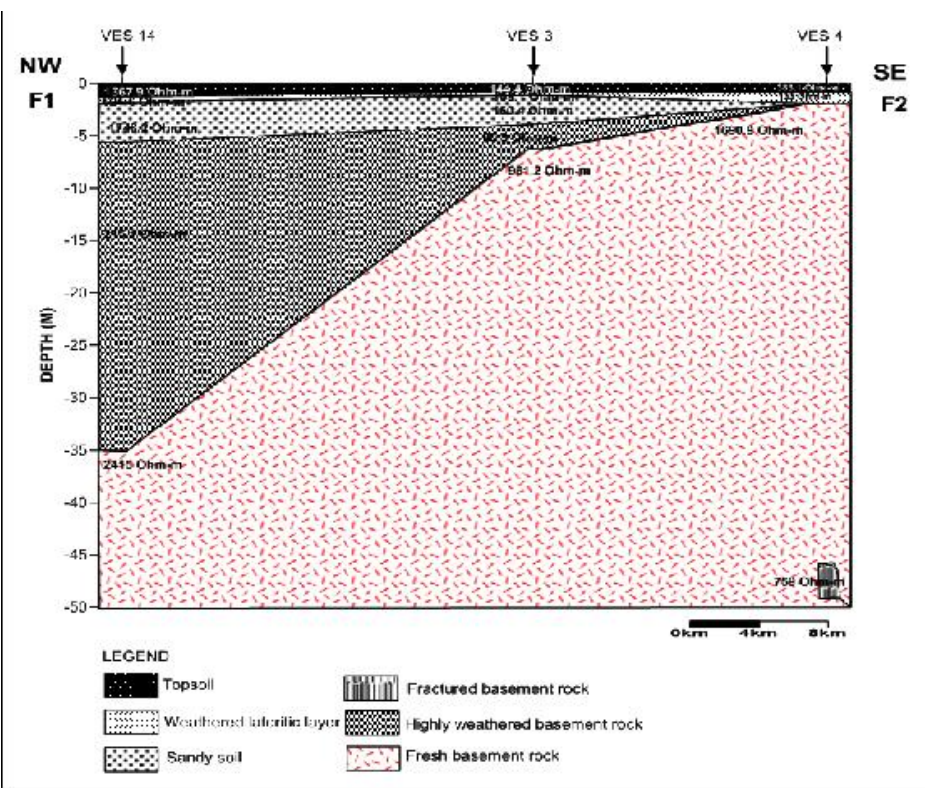

Fig. 14: Geo-electric section along profile F1-F2. 


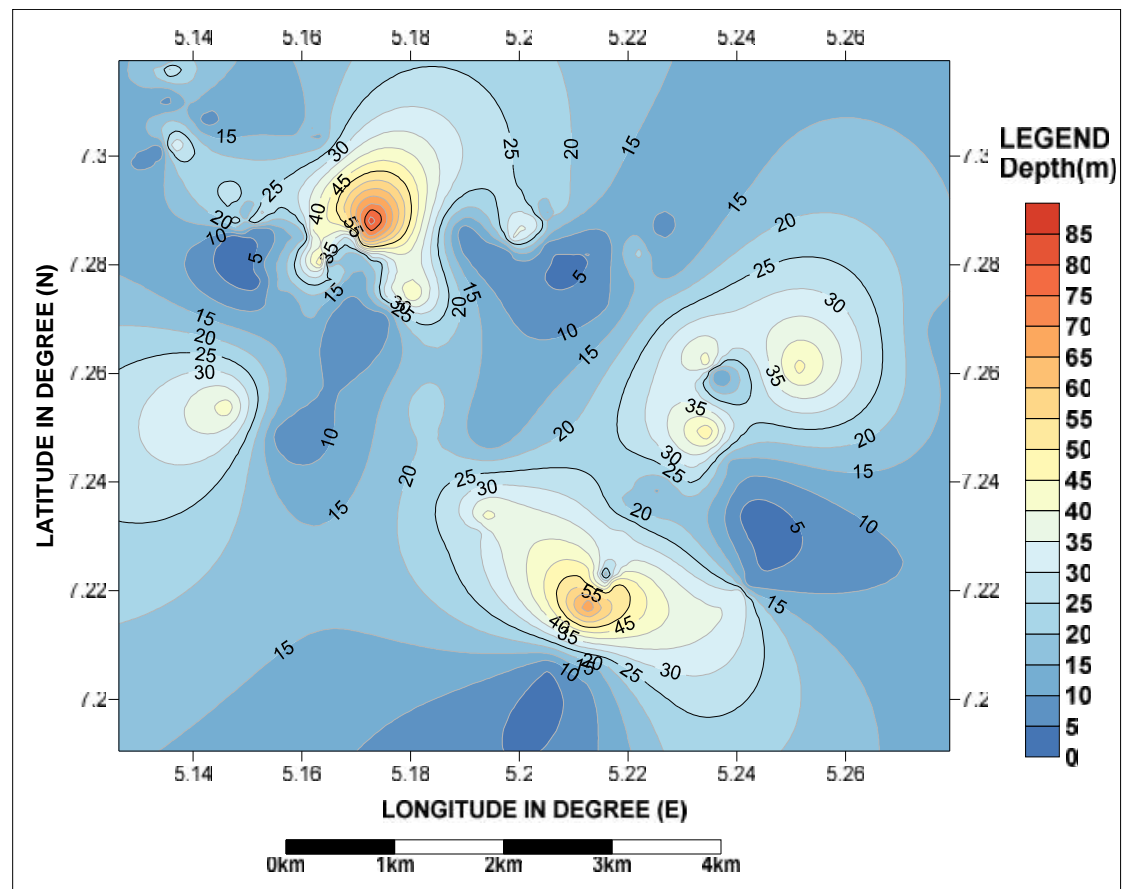

Fig. 15: Depth to Overburden/fractured isopach map of the study area

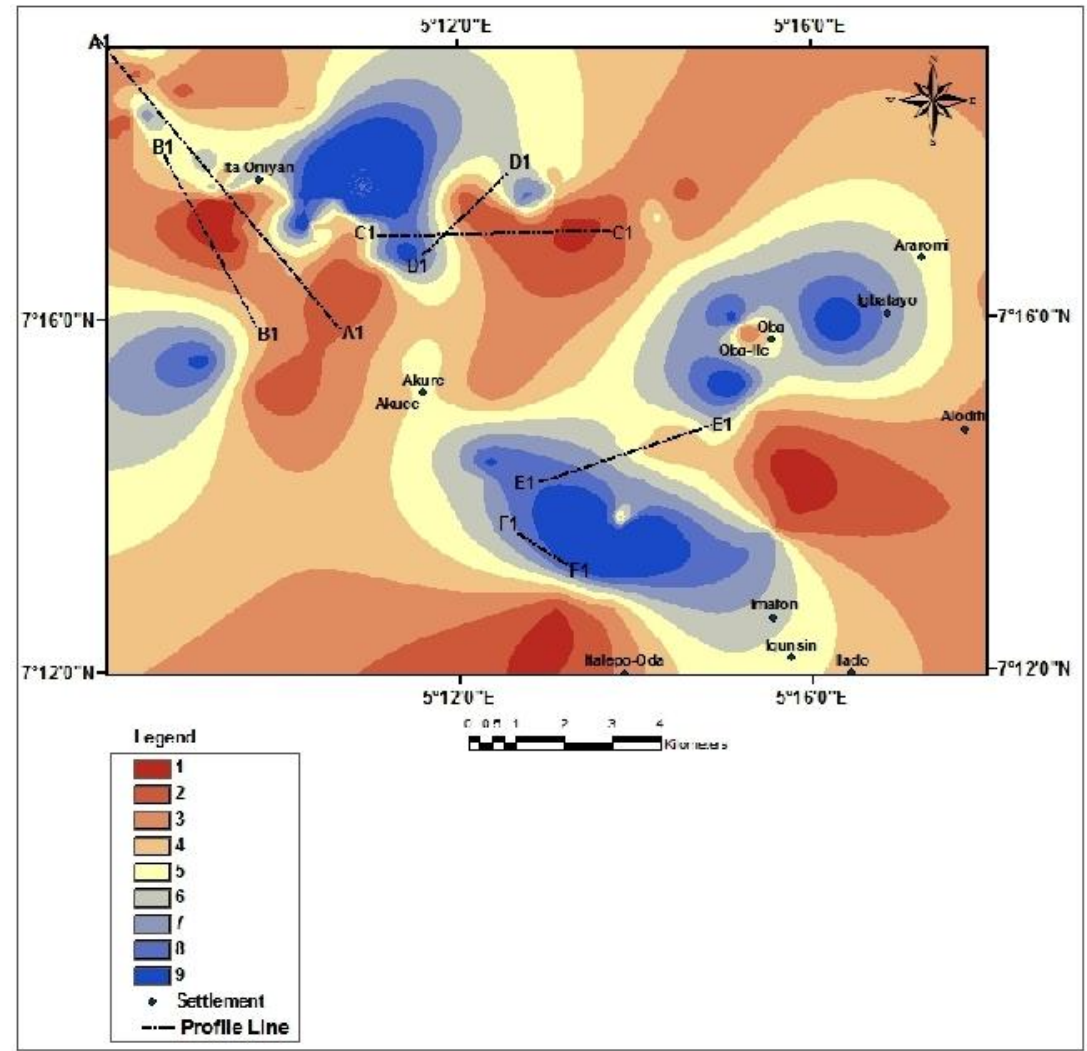

Fig. 16: Reclassified depth to overburden/fractured isopach map of the study area.

\begin{abstract}
Integration of remote sensing and electrical resistivity data

The remote sensing and electrical resistivity maps were reclassified and integrated using the weighted overlay anlyses (Tables 2 and 3 ). The groundwater potential map was analyzed henceforth
\end{abstract}

groundwater potential areas (Fig. 17). This invariably show that a small portion of the study area have high to very high groundwater potential while a great portion of the area falls within the low to very low potential zones. Thus, this is expected due to the lateral discontinuity of basement lithologies. 
Table 2: Weight for all factor maps for overlay

\begin{tabular}{|l|l|l|l|l|}
\hline S/N & FACTOR MAPS & Weights & \% influence & Cell values \\
\hline 1 & Lineament & 0.50 & 50 & $1-9$ \\
\hline 2 & Depth to overburden/fracture zones & 0.50 & 50 & $1-9$ \\
\hline & Total & $\mathbf{1 . 0 0}$ & $\mathbf{1 0 0}$ & \\
\hline
\end{tabular}

Table 3: Calculated suitability table values

\begin{tabular}{|c|c|c|c|c|c|c|c|c|c|c|}
\hline \multirow[t]{2}{*}{ FACTOR MAPS } & \multirow{2}{*}{$\begin{array}{l}\text { Weights } \\
\text { (W) }\end{array}$} & \multicolumn{9}{|c|}{ Reclassified cell values (X) } \\
\hline & & 1 & 2 & 3 & 4 & 5 & 6 & 7 & 8 & 9 \\
\hline Lineament & 0.50 & 0.50 & 1.00 & 1.50 & 2.00 & 2.50 & 3.00 & 3.50 & 4.00 & 4.50 \\
\hline $\begin{array}{l}\text { Depth to } \\
\text { overburden/ } \\
\text { fracture zones }\end{array}$ & 0.50 & 0.5 & 1.00 & 1.50 & 2.00 & 2.50 & 3.00 & 3.50 & 4.00 & 4.50 \\
\hline
\end{tabular}

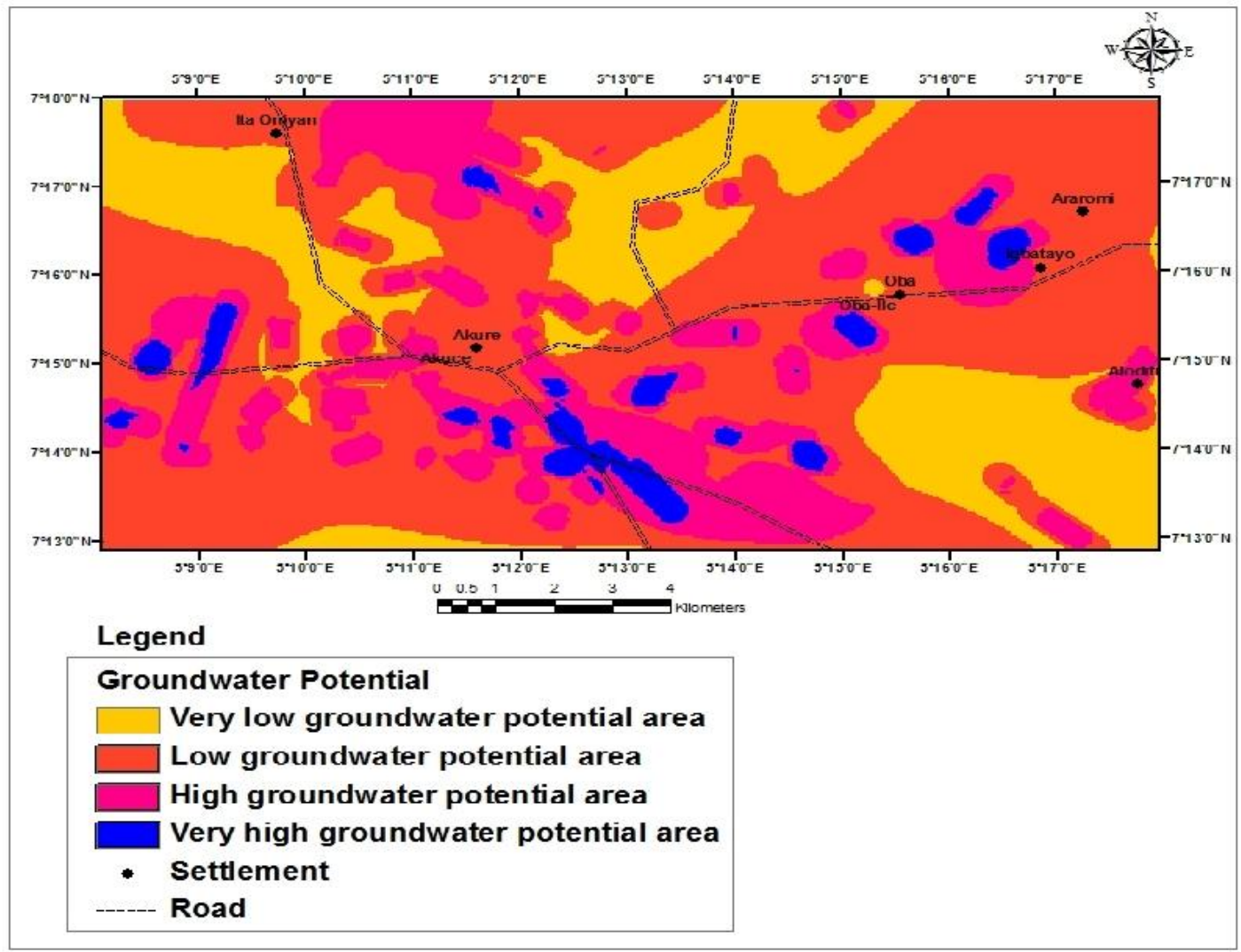

Fig. 17: Groundwater potential map of the study area.

\section{Borehole Yields}

Table 4 shows borehole yield location points while Fig. 18 shows the location points superimposed on the groundwater potential map. It was observed that most of the productive wells are located in areas that significantly have high to very high groundwater potential. An average of 0.9445 litres of groundwater is discharge per second in the all area i.e., approximately 3 , 400litres per hour of groundwater is discharge in th area. However, a critical analysis of borehole yields show that boreholes with the poorest yields pump at a rate of between 0.2 to $0.5 \mathrm{l} / \mathrm{s}$ which is hialv inadequate boreholes pump at the rate of 1.14 to $2.16 \mathrm{l} / \mathrm{s}$. Infact, most areas with good yields are cited in the central to south western portions of the study area as correlated with the model map (Fig. 19). An evaluation of the well data showed that the study area generally has moderate to good borehole yields. It showed that the boreholes located in the high and very high zones of groundwater potentialities have good yields. Here, boreholes with high yields are found around the southwestern part of the area where there is high lineaments density while most of the low yielding boreholes are found far away from the lineaments (Fia. 20). 
Table 4: Borehole data from localities of the study area

\begin{tabular}{|c|c|c|c|c|c|c|}
\hline No & Name & Long. (E) & Lat. (N) & $\begin{array}{l}\begin{array}{l}\text { Elevation } \\
(\mathrm{m})\end{array} \\
\end{array}$ & \begin{tabular}{|l} 
Yield \\
$(\mathrm{l} / \mathrm{s})$
\end{tabular} & \begin{tabular}{|l} 
Depth \\
(m)
\end{tabular} \\
\hline 1 & Police force headquarters (beside Mosque) & 5.23933 & 7.24114 & 369 & 1.21 & 40 \\
\hline 2 & Igoba (II) community. Akure & 5.23278 & 7.29558 & 347 & 0.78 & 27.3 \\
\hline 3 & Ibita Adofire along Idanre Road & 5.16656 & 7.17086 & 328 & 1.2 & 23 \\
\hline 4 & Y \& B's Place Ireakari & 5.20217 & 7.23731 & 356 & 1.24 & 31 \\
\hline 5 & St. Frances Academy. Igoba I & 5.25386 & 7.17222 & 100 & 1.24 & 30 \\
\hline 6 & VIP lodge government house (BH 2) & 5.20856 & 7.23583 & 347 & 1.12 & 40 \\
\hline 7 & VIP lodge government House (BH 1) & 5.20819 & 7.24122 & 347 & 1.13 & 25 \\
\hline 8 & NUT house, Oda Road & 5.21672 & 7.22428 & 362 & 0.75 & 36 \\
\hline 9 & RINGBO & 5.19708 & 7.19992 & 371 & 1.2 & 22.3 \\
\hline 10 & Lafe Inn & 5.16867 & 7.26206 & 374 & 0.9 & 17.87 \\
\hline 11 & Alafe kajola. Ehin Ala & 5.3 & 7.20589 & 335 & 1.23 & 25 \\
\hline 12 & Legbira camp, Idanre & 5.171 & 7.17658 & 222 & 0.93 & 31 \\
\hline 13 & Ondo state electricity board (OSEB) & 5.21747 & 7.24647 & 375 & 0.5 & 41 \\
\hline 14 & Retired bishop house modulore est.Jgoba & 5.241 & 7.29661 & 378 & 0.2 & 20.81 \\
\hline 15 & Deeper life area, Igoba & 5.23492 & 7.297 & 359 & 1 & 30 \\
\hline 16 & Atanlusi layout community off Aule RD & 5.15269 & 7.29069 & 348 & 0.8 & 13 \\
\hline 17 & Adewole Falowo St. Comm. Oke-Aro & 5.18383 & 7.23561 & 406 & 1.12 & 30 \\
\hline 18 & Alaba layout comm. Aule road & 5.15192 & 7.28806 & 374 & 0.2 & 17.78 \\
\hline 19 & Cannan land off ljoka Rd & 5.21069 & 7.20444 & 364 & 1.2 & 28 \\
\hline 20 & Ondo state high court premises & 5.20386 & 7.24892 & 358 & 0.75 & 33 \\
\hline 21 & CAC prim. sch. Oke Igan & 5.18906 & 7.25742 & 332 & 1.26 & 35 \\
\hline 22 & Asamo/Irowo quarters. Oba-lle & 5.26253 & 7.26564 & 326 & 1.1 & 25 \\
\hline 23 & Familusi layout Oke-Aro & 5.17672 & 7.22867 & 334 & 1.26 & 40 \\
\hline 24 & Ikere street. ljapo Estate & 5.20736 & 7.27111 & 351 & 0.8 & 33 \\
\hline 25 & Bishop Gbonigi's residence Oba-lle Estate & 5.24828 & 7.25394 & 335 & 1.23 & 30 \\
\hline 26 & Alaba layout & 5.15339 & 7.28331 & 347 & 0.4 & 30 \\
\hline 27 & St. Louis grammer school & 5.17889 & 7.25111 & 340 & 0.89 & 29 \\
\hline 28 & Scripture union Nigeria & 5.17236 & 7.27039 & 357 & 1.1 & 23 \\
\hline 29 & Ogundipe comm. 2. Ajipowo Estate & 5.16869 & 7.23647 & 350 & 0.9 & 29 \\
\hline 30 & Ondo state high court premises & 5.20314 & 7.24906 & 356 & 1.14 & 30 \\
\hline 31 & St. Louis nursry/primary school & 5.18117 & 7.25067 & 344 & 0.5 & 28 \\
\hline
\end{tabular}

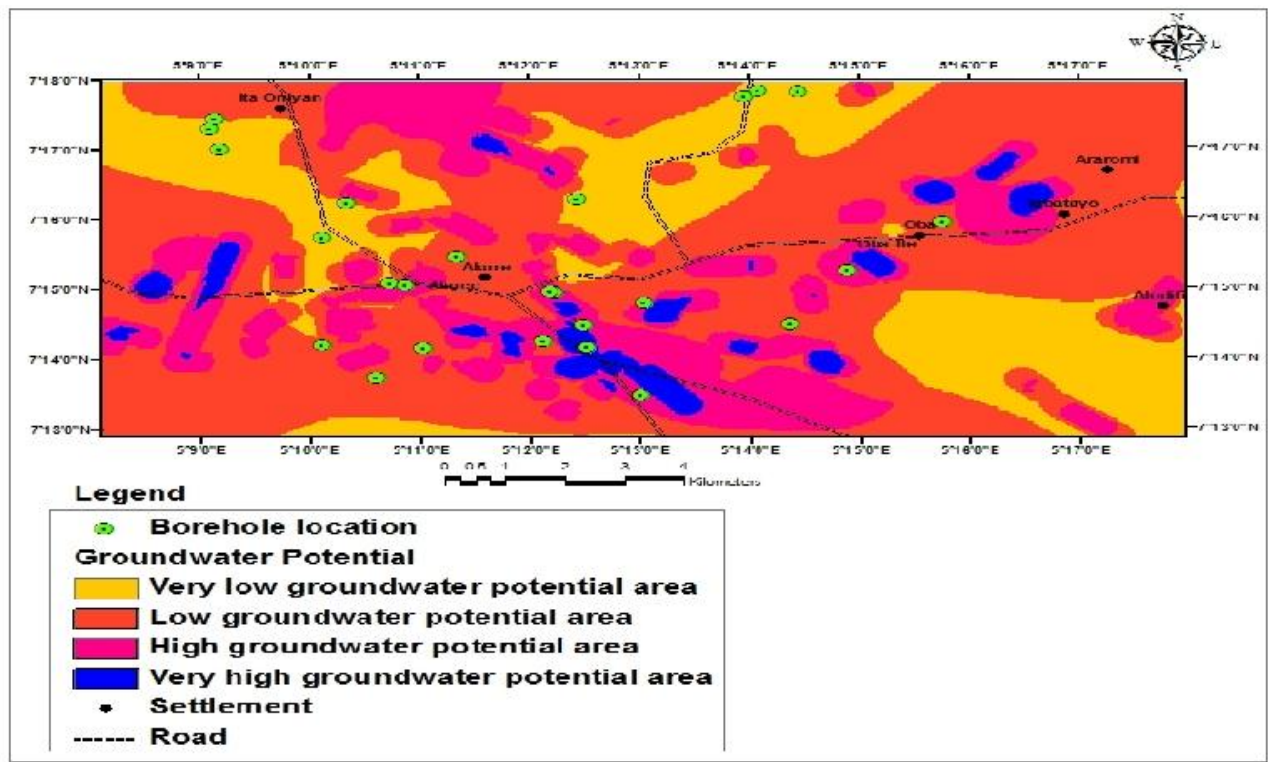

Fig. 18: Sample location map of the study area. 


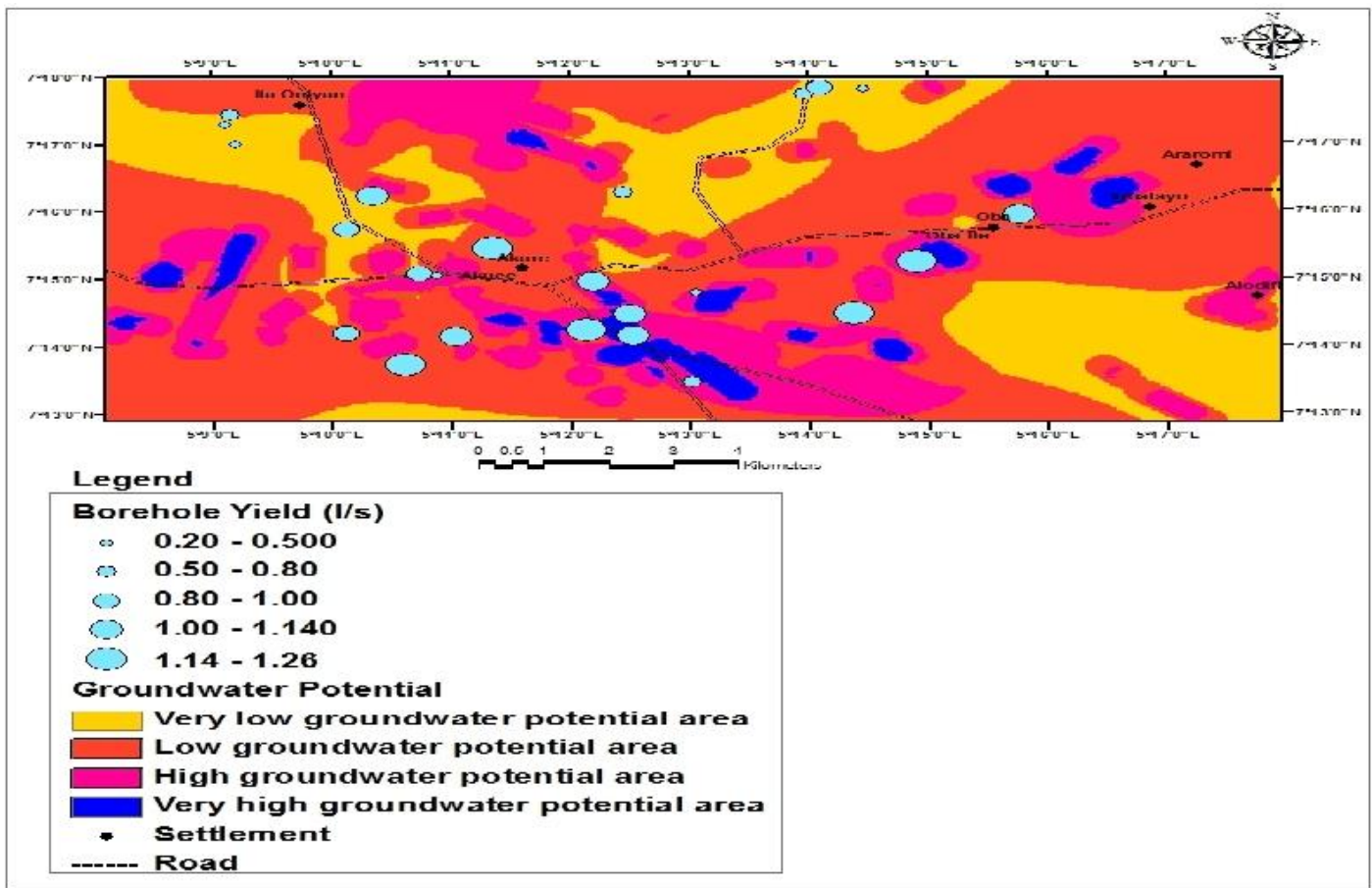

Fig. 19: Borehole yield on groundwater potential map of the study area.

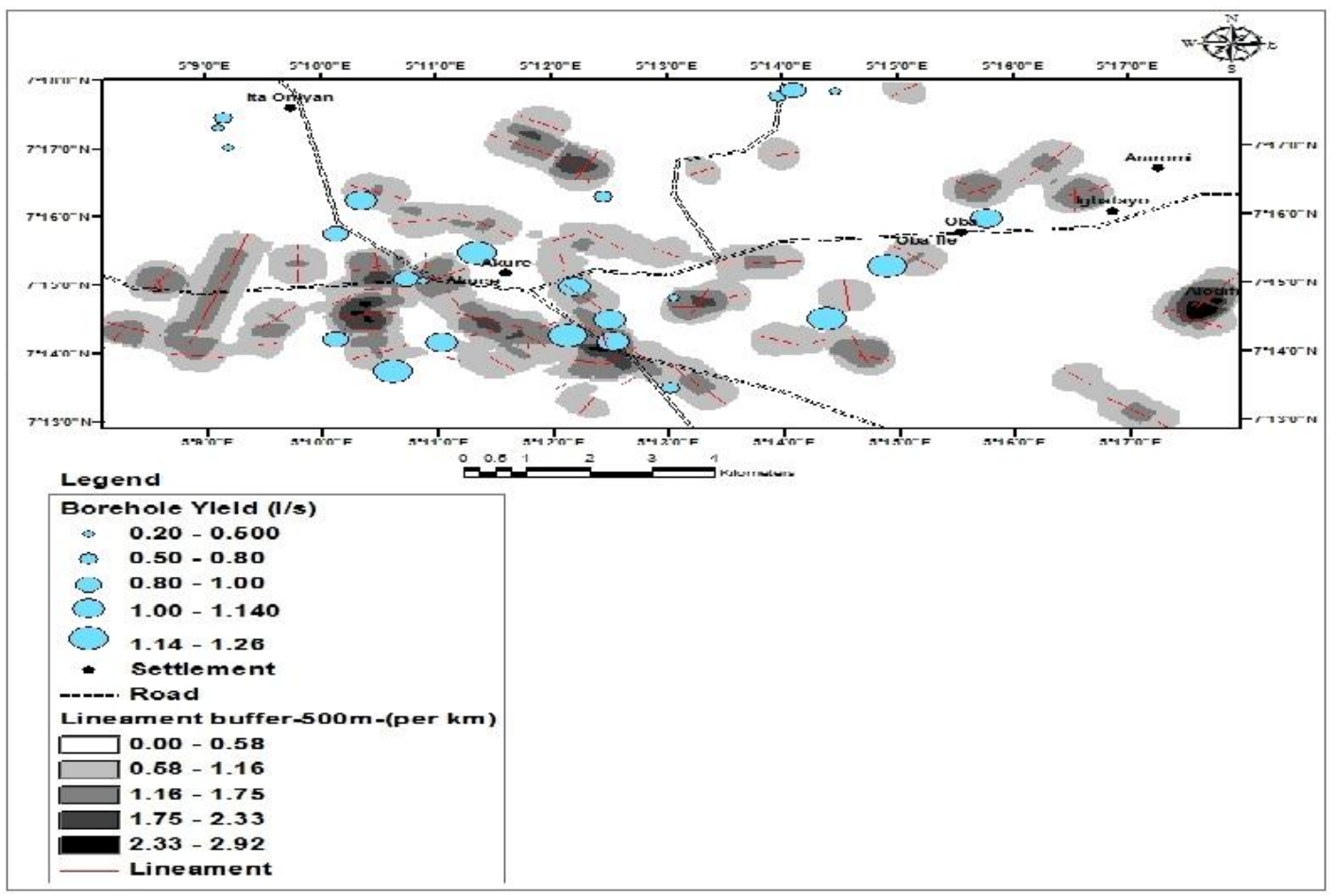

Fig. 20: Borehole yield on lineament map of the study area.

\section{CONCLUSIONS}

The study area is characterized by six geoelectric layers at the subsurface; the topsoil, weathered lateritic layer, sandy soil, highly weathered basement, fractured basement rock, and fresh basement rock. Thus, the sandy soil layer, the highly weathered and the fractured layers constituted the aquifers in the area

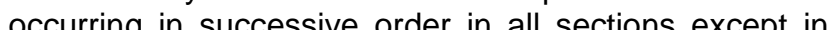

cases of lithological disturbance such as faulting. Those VES points within good potential zones have thick overburden and in some cases have highly fractured bedrocks. The overburden thickness showed that the depths to fresh basement range from 0 on the surface through $30 \mathrm{~m}$ in averagely-shallow depth of weathering, and to $80 \mathrm{~m}$ in deeply-weathered area. The groundwater potential map of the area showed four potential zones; verv Inw Inw hish and verv hinh arnı indwater nntential 
areas. The most promising potential zone in the area is related to the lowlands where overburden is thick and chemical weathering is prominent while most of the zones with fair groundwater potential lie in the massive basements units of high elevation, low infiltration and absence of fractured bedrocks. Boreholes with good yields fall within zones of high groundwater potentials while boreholes with poor yield correlated with those low groundwater zones. The study also show that groundwater exploration is best carried out with a combination of remote sensing and resistivity methods.

\section{REFERENCES}

Akinluyi, F. O., 2012. Integration of Geophysical and Remotely Sensed Data in Regional Groundwater Evaluation in the Basement Complex of Ondo State, Southwestern Nigeria. Unpublished PhD thesis, Department of Geology, Obafemi Awolowo University, lle-lfe, Osun State, Nigeria. 360.

Akintorinwa, O. J and Olowolafe T. S., 2012. Geoelectric evaluation of groundwater prospect within Zion Estate, Akure, Southwest, Nigeria. International Journal of Water Resources and Environmental Engineering, 5, (1): 12-28.

Anifowose, A. Y. B and Kolawole, F., 2012. Tectonohydrological study of Akure metropolis, Southwestern Nigeria. Special Publication of the Nigerian Association of Hydrological Sciences. Hydrology for Disaster Management: 106-120.

Dibal, H. U., Ogbeni, E. M., Yenne, E. Y., Daspan, R. I and Daku, S. S., 2016. An Integrated Method of Groundwater Potential Mapping of parts of Naraguta Sheet $168 \mathrm{NE}$, North-Central Nigeria. Water Resources (2016) 26:55-78. Journal of Nigeria Association of Hydrogeologists. Pgs. 5578

Goki, N. G., Ugodulunwa, F. X. O., Ogunmola, J. K., Oha, I. A and Ogbole, J. O., 2010. Geological Controls for Groundwater Distribution in the Basement Rocks of Kanke, Central Nigeria from Geophysical and Remotely Sensed Data. African Journal of Basic \& Applied Sciences 2 (3-4): 104-110.

Greenbaum, D., Carruthers, R. M., Pear, R. J. T., Shedlock, S. J., Jackson, P. D., Mtetwa, $S$ and Amos, B. J., 1993. Groundwater exploration in southeast Zimbabwe using remote sensing and ground geophysical techniques. British Geological Survey, Overseas Geology Series, Technical Report WC/93/26, Project Completion Report. 10.

Kim, G., Lee, J and Lee, K., 2004. Construction of a Lineament maps related to groundwater occurrence with Arcview and Avenue ${ }^{\mathrm{TM}}$ scripts. Journal of Computer and Geosceinces. Volume 30 issue 9-10. 1117-1126.
Lean, G., Hinrichsen, D and Markham, A., 1990. Atlas of the environment. New York, Prentice Hall Press. 31.

Mogaji, K. A., Aboyeji, O. S and Omosuyi, G. O., 2011. Mapping of Lineaments for Groundwater Targeting in Basement Complex Area of Ondo State using Remotely Sensed Data and Geography Information System (GIS) Techniques. International Journal of Water Resources and Environmental Engineering, 3, (7): 150-160.

Odeyemi, I. B., Anifowose, A. Y. B and Asiwaju-Bello, Y. A., 1999. Remote Sensing Fracture Characteristics of Pan African Granite Batholiths in the Basement Complex of Parts of South Western Nigeria. Journal of Technoscience, 3, 56-60.

Olarewaju, V. O., 1981. Geochemistry of the charnockite and granitic rocks of the Basement Complex around Ado-Ekiti-Akure, S.W. Nigeria. Unpublished PhD thesis, University of London, London.

Olorunfemi, M. O and Fasuyi, S. A., 1993. Aquifer types and the geoelectric/hydrogeologic characteristics of part of the central basement terrain of Nigeria (Niger State). Journal of African Earth Sciences, 16, (3): 309-317.

Olorunfemi, M. O., Ojo, J. S and Akintunde, O. M., 1999. Hydro-geophysical Evaluation of the Groundwater potentials of the Akure Metropolis, Southwestern Nigeria. Journal of Mining and Geology, 35, (2): 207-228.

Sahu, P. C and Sahoo, H., 2006. Targeting Ground Water in Tribal Dominated Bonai Area of Grpught - Prone Sundargarh District, Orissa, India - A Combined Geophysical and Remote Sensing Approach. Journal of Human Ecology, 20, (2): 109-115.

Saxena, P. R., Sudarshan, V., Chandrasheka, B. R and Saxena, M. R., 2004. Application of Remote Sensing, GIS and Geo-Electrical Methods for Ground Water Exploration in Zaheerabad, Medak Dist. A.P., India. PS ICWG II /IV ThS 13. 13-16.

Srivastava, V. K., Giri, D. N and Bharadwaj, P., 2012. Study and Mapping of Ground Water Prospect using Remote Sensing, GIS and Geoelectrical resistivity techniques - a case study of Dhanbad district, Jharkhand, India. J. Ind. Geophys. Union, 16, (2): 55-63.

Worthington, P. R., 1977. "Geophysical Investigations of Groundwater Resources in the Kalahari Basin".Geophysics. 42, (4): 838-849.

Yadav, G. S and Singh, S. K., 2007. Integrated resistivity surveys for delineation of fractures for groundwater exploration in hard rock areas. Journal of Applied Geophysics, 62: 301-312. 
Yenne, E. Y., 2015. Integration of Remote Sensing and Electrical Resistivity Methods in groundwater potentials mapping of Akure, Southwestern Nigeria. Unpublished M.Tech. Thesis, Federal Yenne, E. Y., Anifowose, A. Y. B, Dibal, H. U and Nimchak, R. N., 2015. An Assessment of the Relationship between Lineaments and Groundwater Productivity in a Part of the Basement Complex, Southwestern Nigeria. IOSR Journal of Environmental Science, Toxicology and Food Technology (IOSRJESTFT) e-ISSN: 2319-2402, p-ISSN: 23192399. Volume 9, Issue 6 Ver. I (Jun. 2015), PP 23-35 www.iosrjournals.org. 